Удк 339.138

I. О. Терешенко,

к.е.н., дочент кафедри маркетингу,

Полтавська державна аграрна академія, м. Полтава

ORCID ID: 0000-0001-5176-6522

B. О. Кібальник,

здобувач вищої освіти спечіальності "Менеджмент",

Полтавська державна аграрна академія, м. Полтава

ORCID ID: 0000-0002-6374-1469

DOI: $10.32702 / 2306-6814.2019 .20 .56$

\title{
МАРКЕТИНГОВІ АСПЕКТИ
}

СТРАТЕГІЧНОГО УПРАВ $\Lambda$ ІННЯ

ПІАПРИЕМСТВОМ

\author{
I. Tereshchenko, \\ $\mathrm{PhD}$ in Economics, Associate Professor in Department of Marketing, Poltava State Agrarian Academy, Poltava \\ V. Kibalnik, \\ applicant, Poltava State Agrarian Academy, Poltava
}

\section{MARKETING ASPECTS OF STRATEGIC ENTERPRISE MANAGEMENT}

Стаття розкриває сутність маркетингових аспектів стратегічного управління підприємством. Проаналізовано визначення поняття "маркетингова стратегія". Визначено фактори, що впливають на формування системи маркетингового стратегічного управління. Розкрито етапи формування системи маркетингового стратегічного управління підприємством. Зазначено, що використання маркетингових інструментів формування стратегії підприємства підвищує ефективність стратегії загалом. Досліджено основні елементи системи маркетингового менеджменту підприємства. Доведено необхідність упровадження випереджаючого, тобто маркетингово орієнтованого, управління у підприємстві. Обгрунтовано сутність та загальні положення оцінки ефективності маркетингової стратегії підприємства та напрями її удосконалення.

Система маркетингового управління підприємства відображає багатофункціональну систему взаємопов 'язаних елементів, які утворюють єдине ціле. Доведено, що структуру системи маркетингового менеджменту утворюють елементи, реалізація яких забезпечує конкурентоспроможність підприємства. Вони можуть бути використанідля покращення якості управління та підвищення рівня конкурентоспроможності виробничого підприємства. У статті наведено визначення маркетингового управління діяльністю підприємства та класифікацію маркетингових стратегій. Запропоновано етапи здійснення маркетингового стратегічного управління діяльністю підприємства. Результатом застосування методики є формування рекомендацій щодо удосконалення системи маркетингового стратегічного менеджменту підприємства, що дадуть змогу підвищити його конкурентоспроможність. Встановлено, що в умовах ринкової економіки керівникам підприємств необхідно використовувати маркетингові інструменти удіяльності, що пов'язано із зростанням конкуренції на ринку. Обгрунтовано, що система маркетингового стратегічного управління підприємством є основою ефективності його діяльності, що впливає на конкурентоспроможність та визначає напрями подальшого розвитку.

The article reveals the essence of marketing aspects of strategic enterprise management. The definition of the term "marketing strategy" is analyzed. The factors influencing the formation of the marketing strategic management system are identified. The stages of formation of the system of marketing strategic management of the enterprise are revealed. It is noted that the use of marketing tools for the formation of enterprise strategy increases the effectiveness of the strategy as a whole. The basic elements of the enterprise marketing management system are investigated. The necessity 
of introducing a leading, marketing oriented, management in the enterprise has been proved. The essence and general provisions of the estimation of the effectiveness of the marketing strategy of the enterprise and directions of its improvement are substantiated.

The enterprise marketing management system reflects a multifunctional system of interconnected elements that form a single whole. It is proved that the structure of the marketing management system is formed by elements, the implementation of which ensures the competitiveness of the enterprise. They can be used to improve the quality of management and enhance the competitiveness of the manufacturing enterprise. The article describes the definition of marketing management system of the enterprise and classification of marketing strategies. The stages of realization of marketing strategic management of activity of the enterprise are offered. The result of the application of the methodology is to formulate recommendations for improving the strategic marketing management system of the enterprise, which will allow to increase its competitiveness. It is established that in a market economy, business executives need to use marketing tools in activities that are associated with increased competition in the market. It is substantiated that the system of marketing strategic management of an enterprise is the basis for the effectiveness of its activity, which affects the competitiveness and determines the directions of further development.

КлючоВі слова: стратегічне упраВління, маркетингові стратегії, ринкові інструменти, ефектиВність. Key words: strategic management, marketing strategies, market instruments, efficiency.

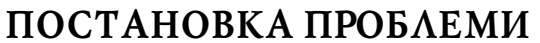

В умовах ринкової економіки успішність роботи підприємства здебільшого залежить від ефективного планування і, в першу чергу, від правильно обраної стратегії. Маркетингова стратегія підприємства - це сукупність ї̈ основних цілей та засобів досягнення даних цілей. Розробляти стратегічні дії підприємства - це значить визначати загальний напрямок ії діяльності. Стратегія - це не просто функція часу, а також функція напрямку. Вона включає в себе сукупність глобальних ідей розвитку підприємства.

У колі теоретиків і практиків особливу зацікавленість викликають питання формування та реалізації маркетингової стратегії підприємств, оскільки на сучасному етапі розвитку вони набуває клієнтоорієнтованого характеру. Це підвищує значущість маркетингової складової у забезпеченні ефективного функціонування й розвитку підприємства. Питання формування та реалізації маркетингових аспектів стратегічного управління підприємства та оцінка їх ефективності $\epsilon$ досить актуальними для підприємств.

\section{АНА $І$ IЗ ОСТ АНHIX НАУКОВИХ АОС $\triangle$ IАЖЕНЬ}

Значний внесок у дослідження питань використання маркетингових інструментів стратегічного управління діяльністю підприємств зробили такі відомі зарубіжні та вітчизняні вчені: Г. Армстронг, Г. Ассель, Л.В. Балабанова, О.В. Березін, Н.В. Бутенко, С.С. Гаркавенко, О.Л. Каніщенко, К.Л. Келлер, Ф. Котлер, М.В. Конишева, А.П. Міщенко, Н.К. Мойсеєва, В.А. Пархоменко, В.В. Писаренко, А.О. Старостіна, О.С. Телетов, В.А. Шаповалов, З.Є. Шершньова.

Сьогодні існує велика кількість різноманітних маркетингових інструментів, запропонованих різними дослідниками і науковцями. Проте нині немає системної класифрікації можливих стратегій управління підприємством 3 використанням маркетингових інструментів.

\section{META CTATTI}

Метою статті $€$ дослідження наукових позицій щодо сутності маркетингових аспектів стратегічного управління, класифрікації маркетингових стратегій та ролі маркетингових інструментів у стратегічному управлінні підприємством.

\section{ВИКААА ОСНОВНОГО МАТЕРІААУ АОС $І$ IАХЕНHЯ}

За динамічних умов зміни зовнішнього маркетингового середовища підприємства успішна економічна діяльність неможлива без ефективного управління і стратегічного планування. Вирішальним фрактором такого успіху є розробка і використання маркетингових інструментів стратегічного управління, що зможе адаптувати підприємство до змін зовнішнього середовища. Вибір стратегіï залежить від багатьох зовнішніх і внутрішніх факторів, найбільш важливими серед яких $€:$ фрактори, що характеризують стан галузі та умови конкуренції, а також фактори, що характеризують конкурентні можливості підприємства, його ринкову позицію та потенціал [7].

Розробляючи стратегію, підприємства прагнуть знайти і втілити спосіб вигідно і тривалий час конкурувати в своїй галузі. Універсальної стратегії не існує, i лише стратегія, що узгоджена з умовами конкретної галузі, досвідом та капіталом, яким володіє підприємство, може принести успіх.

Провівши детальний аналіз маркетингових аспектів стратегічного управління, дійшли до висновку, що найактуальнішими класифікаційними ознаками для фрормування маркетингових стратегій підприємств $€$ [1-10]: термін розробки та реалізації стратегії, позиція підприємства на ринку, стан ринкового попиту, загальноекономічний стан підприємства, співвідношення відносної ринкової частки підприємства та темпу росту ринку (див. табл. 1).

Маркетингові стратегії підприємств необхідно розглядати залежно від терміну розробки та реалізації стратегії: 
короткострокові стратегії (до одного року); середньострокові (від одного до трьох років і грунтуються на короткострокових стратегіях та перспективах розвитку ринку); довгострокові стратегії (більше трьох років, ті стратегії, що будуть ефективними у довгостроковій перспективі).

Друга класифрікаційна ознака - позиція, що підприємство займає на ринку. Цей підхід був сорормований Ф. Котлером, відповідно до нього стратегії поділяються на: стратегії лідерів, стратегії для претендентів на лідерство, стратегії для послідовників, стратегії для мешканців ніш і для слабкого бізнесу [10, с. 218].

Основним завданням стратегії лідерів є утримання своїх позицій i, можливо, перетворення на домінуючого лідера, для цього потрібно розширювати ринок, збільшувати частку ринку або захищати частку ринку шляхом наступу чи оборони [4, с. 24-25].

У разі розширення ринку загалом, як правило, виграє насамперед лідер, тому що до нього відходить найбільший відсоток нових продажів, за рахунок нових покупців, або збільшення інтенсивності споживання. Прагнучи збільшити частку ринку, підприємство має враховувати обмеження антимонопольного законодавства і той фракт, що після досягнення певного розміру подальше зростання може призвести до зменшення віддачі від масштабу. Оскільки частку ринку необхідно відвоювати у конкурентів, для цього застосовують наступальні стратегії [4, с. 24-25].

Стратегії для претендентів на лідерство $€$ доцільними в галузях, де віддача від масштабу зростає, а отже, лідерство забезпечує конкурентну перевагу по витратах. Рекомендовані такі стратегії [10, с. 219-220]:

- "фронтальний наступ", або пряме протистояння сильним сторонам конкурента;

- "фрлангова атака", або використання недоліків конкурента;

- "спроба оточення", або одночасний наступ на кількох фронтах;

- "обхідний маневр", або захоплення незайнятих просторів;

- "партизанська війна" - це проведення невеликими силами атак по всій території супротивника (рекламні акції, спеціальне стимулювання попиту, PR-акції).

Стратегії для послідовників - для підприємств, що не $\epsilon$ лідерами у галузі, поводяться як послідовники і свідомо відмовляються від наступальних стратегій. Водночас вони цілком задоволені своєю позицією, бо мають стабільний прибуток. Розрізняють чотири стратегії послідовників: наслідувач підробляє продукт лідера і упаковку, реалізуючи товар невеликими партіями через посередників; двійник копіює продукцію, систему розподілення, рекламну кампанію конкурента, виводить товар на ринок за нижчою ціною під схожою назвою; імітатор щось копіює у лідера, але зберігає відмінності в упаковці, рекламі, цінах тощо [10, с. 219-220].

Стратегії для мешканців ніш. Ніша - це вузька група покупців, потреби яких недостатньо задовольняють конкуренти. Для нішерів можуть бути доцільним застосування таких стратегій [10, с. 219-220]:

1) підтримання позицій (при невеликих можливостях і ніші, і нішера);

2) інтеграція з іншим виробником (якщо можливості ніші більші, ніж нішера);
Таблиця 1. Класифікація маркетингових стратегій управління підприємством

\begin{tabular}{|l|l|}
\hline \multicolumn{1}{|c|}{ Ознаки класифікації } & \multicolumn{1}{|c|}{ Види маркетингових стратегій } \\
\hline $\begin{array}{l}\text { Термін розробки та } \\
\text { реалізації стратегії }\end{array}$ & $\begin{array}{l}\text { Короткострокові, середньострокові } \\
\text { та довгострокові стратегії }\end{array}$ \\
\hline Позиція підприємства & $\begin{array}{l}\text { Стратегія лідера, претендента на } \\
\text { лідерство, послідовника, стратегія } \\
\text { для мешканців ніш }\end{array}$ \\
\hline Стан ринкового попиту & $\begin{array}{l}\text { Стратегія стимулюючого } \\
\text { маркетингу, синхромаркетингу, } \\
\text { підтримуючого маркетингу, } \\
\text { ремаркетингу та демаркетингу }\end{array}$ \\
\hline $\begin{array}{l}\text { Загальноекономічний } \\
\text { стан підприємства }\end{array}$ & $\begin{array}{l}\text { Стратегія виживання, стабілізації і } \\
\text { росту }\end{array}$ \\
\hline $\begin{array}{l}\text { Метод обрання } \\
\text { цільового ринку }\end{array}$ & $\begin{array}{l}\text { Стратегія товарної спеціалізації, } \\
\text { сегментної спеціалізації, } \\
\text { селективної (вибіркової) } \\
\text { спеціалізації, односегментної } \\
\text { концентрації та стратегія повного } \\
\text { охоплення ринку }\end{array}$ \\
\hline $\begin{array}{l}\text { Співвідношення } \\
\text { відносної ринкової } \\
\text { частки підприємства та } \\
\text { темпу росту ринку } \\
\text { збуту }\end{array}$ & $\begin{array}{l}\text { Стратегія розвитку, підтримання, } \\
\text { збирання врожаю та елімінації }\end{array}$ \\
\hline
\end{tabular}

Джерело: розроблено на основі [2-11].

3) лідерство в ніші (якщо можливості ніші і нішера синхронно зростають);

4) вихід за межі ніші (якщо можливості нішера більші, ніж потрібно для цієї ніші).

Підприємство, конкурентні позиції якогоє слабкими, може використовувати стратегії: обережного наступу (застосовується за наявності фрінансових і кадрових ресурсів, мета - поступово збільшити частку ринку і покращити позиції); оборони і зміцнення (передбачає збереження досягнутих обсягів продажу, частки ринку, прибутковості і конкурентних позицій); негайного відступу (у випадку відсутності покупців проводиться продаж активів іншій фрірмі чи припинення діяльності); "збирання врожаю" (використовується при виході підприємства з галузі і передбачає мінімізацію реінвестицій і максимізацію короткострокових грошових потоків) [10, с. 219-220].

Залежно від стану ринкового попиту (третя ознака класифрікації) існують такі види стратегій [7]:

- стимулюючого маркетингу - застосовується за відсутності попиту, коли товар сприймається як такий, що не має споживчої цінності, непотрібний для місцевих умов або ринок не підготовлений до появи такого продукту;

- синхромаркетингу - застосовується для ринку, що характеризується сезонними коливаннями;

- підтримуючого маркетингу - застосовується, коли стан попиту повністю задовольняє підприємство, відповідає його виробничим можливостям і маркетинговій програмі (повний попит);

- ремаркетингу - застосовується, коли спостерігається падіння попиту;

- демаркетингу - доцільно застосовувати, коли попит значно перевищує пропозицію (припинення стимулювання збуту, перегляд рекламної кампанії, цінової політики).

Четвертою ознакою поділу маркетингових інструментів стратегічного управління $€$ загальноекономічний стан підприємства та його маркетингові спрямування. 
Відповідно до цього розрізняють такі види стратегій: виживання (застосовується в умовах кризи, коли підприємство перебуває на межі банкрутства. Основна мета полягає у виході з кризового стану шляхом перегляду і перебудови всього маркетингового комплексу); стабілізації (використовується за умов швидкого або несподіваного падіння базових показників підприємства, чи коли розвиток має коливальний характер, передбачає вирівнювання показників з переходом до стратегії росту); стратегія росту (передбачає зростання обсягів продажу, прибутку, капіталу та інших показників; поділяються на такі різновиди: інтенсивного (органічного) росту, інтеграційного росту та диверсифрікації [7].

Метод обрання цільового ринку - це п'ята ознака поділу, відповідно до якої маркетингові стратегії поділяються на стратегію товарної спеціалізації, сегментної спеціалізації, селективної (вибіркової) спеціалізації, односегментної концентрації та стратегія повного охоплення ринку [7].

Стратегія товарної спеціалізації передбачає орієнтацію діяльності підприємства на певний різновид товару, який пропонується різним групам споживачів у межах загального ринку. Перевагою стратегії товарної спеціалізації $€$ можливість постійного вдосконалення даного різновиду товару й досягнення високого іміджу у галузі цього товару [7].

Стратегія сегментної спеціалізації означає орієнтацію діяльності на задоволення різних потреб одного ринкового сегмента. Стратегія селективної (вибіркової) спеціалізації полягає у виборі цільових сегментів у межах загального ринку без їх відповідності товарній або сегментній ознаці. Основними факторами вибору цільових ринків у цьому випадку $є$ їхня прибутковість та відповідність ресурсам і виробничим можливостям підприємства.

Стратегія односегментної концентрації передбачає вибір як цільового одного ринкового сегмента і зосередження на ньому діяльності підприємства. Стратегія повного охоплення ринку відтворює прагнення фрірми задовольнити потреби загального ринку в цілому [7].

Наступна класифікаційна характеристика запропонована засновником Бостонської консалтингової групи Брюсом Д. Хендерсеном - співвідношення відносної ринкової частки фрірми та темпу росту ринку збуту. Така класифікація та поділ діяльності компанії на групи допомагає визначити адекватну стратегію та фрінансування заради досягнення лідерських позицій чи прибутковості галузі (продукту, послуги) [12]:

- стратегія розвитку - рекомендована для підприємств ("диких кішок"), частка ринку якихє невеликою, проте темпи зростання досить високі, діяльність підприємств має бути спрямована на залучення інвестицій та розвиток бізнесу;

- стратегія підтримання - її використовують для так званих "дійних корів", коли частка ринку та темпи зростання $є$ високими і для збереження позицій на ринку, який зростає, потрібні значні інвестиції, що залучають із зовнішніх джерел фрінансування;

- стратегія збирання врожаю (використовують підприємства "зірки") передбачає отримання короткострокового прибутку в максимально можливих розмірах навіть за рахунок скорочення частки ринку. Таку стратегію застосовують передусім для фрірм, темпи зростання яких сповільнилися.

Формування маркетингової стратегії пов'язані із вирішенням проблеми якнайшвидшого досягнення поставлених цілей, в умовах внутрішнього середовища та ситуації на ринку. У такому випадку цілі $€$ результатом, а стратегія інструментом їх досягнення. Для стабільного довготривалого розвитку підприємства замало сфрормувати ефективну стратегію та втілити ії̈ в реальність, необхідно також передбачити систему заходів, що допоможуть вчасно реагувати на зовнішні зміни, вимоги ринку, зростаючу конкуренцію. Тут доречне твердження А. Томпсона та А. Стрікленда [9, с. 189] "...стратегія підприємства складається із запланованих дій (намічена стратегія) і необхідних виправлень (незаплановані стратегічні рішення) у разі непередбачених обставин. Тобто стратегію найкраще розглядати як комбінацію із запланованих дій і рішень по швидкому пристосуванню до прогресивних технологій і нових позиції на конкурентному полі боротьби".

Оскільки єдиного загальноприйнятого алгоритму формування маркетингової стратегії не існує, то розглянемо найбільш відомі у світовій практиці. Так, 3. Шершньова [12, с. 246-250] наголошує, що формування стратегії необхідно розглядати як невід'ємну складову системи стратегічного управління, що передбачає визначення особливостей процесу розробки окремих стратегій і "стратегічного набору" підприємства.

Мінцберг Г. [5] у 1984 році запропонував використовувати в процесі формування стратегії три підходи, в основі яких використовують планову і підприємницьку моделі, та модель "навчання на досвіді". При використанні планової моделі стратегія проходить стадію розробки в так званому "плановому режимі". Тут передбачається залучення висококваліфікованих фрахівців, які на основі своїх знань і вмінь, використовуючи наукові методи, визначають можливі й бажані результати. Після чого визначають найефективніші шлях їх досягнення.

Підприємницька модель використовує методи розробки стратегій, що грунтуються на багатому особистому досвіді керівника-підприємця і його баченні майбутнього. Особливу роль тут відіграють знання, логіка та інтуїція, що допомагають у складанні реального плану дій задля досягнення поставлених цілей.

Модель "навчання на досвіді" використовується в умовах нестабільності ринку. Особливою рисою цієї моделі $\epsilon$ неодмінне врахування зовнішніх реакцій з боку ринку, у зв'язку з чим є можливість коректування стратегії підприємства. Цей процес - не планований, а до певної міри раптовий і несподіваний.

Керівник, який знаходиться на найвищому щаблі управлінської ієрархії підприємства, а точніше, його частка участі в процесі формування стратегії, покладена в основу алгоритму А. Томпсона й А. Стрікленда [9], і в залежності від певного співвідношення науковці пропонують такі підходи до побудови стратегії:

- одноосібний підхід, коли керівник підприємства $€$ головним "диригентом", "стратегом-будівельником" стратегічної піраміди організації, має вирішальний голос у формуванні й визначенні стратегії;

- підхід, заснований на делегуванні, коли керівник передає весь обсяг робіт групі підлеглих виконавців; 
процес фрормалізації маркетингової стратегії зводиться до виконання планової роботи, спостерігається ізольованість у ланці "керівник-безпосередній виконавець";

- підхід, заснований на співробітництві, $є$ проміжним між першим і другим підходами: над формуванням стратегії працюють планові органи і майбутні головні виконавці - під наглядом керівника;

- підхід, заснований на конкуренції, коли виконавців зацікавлені у розробці стратегії, процес розробки стратегії проходить у боротьбі між виконавцями за першість ідей у пошуку діючих методів і способів досягнення поставлених цілей, хоча цей підхід може мати негативний вплив на мікроклімат управлінського колективу [7, с. 61].

Існує також безліч інших підходів щодо формування маркетингової стратегії. Зокрема І. Ансоффр [1] пропонує такий шлях фрормування стратегії: аналіз перспектив підприємства, аналіз позиції у конкурентній боротьбі й вибір стратегії.

У свою чергу, Ф. Котлер [10] спробував виділити й побудувати більш уніфіковану модель процесу розробки стратегії. Він пропонує наступну послідовність етапів: фрормування й декларування програми підприємства, постановка завдань і визначення мети, розробка планів розвитку господарського портфеля, реалізація стратегії росту.

Процес формування маркетингової стратегії має проходити в три етапи: 1) визначення сорери бізнесу, з подальшим фрормуванням основної стратегічної мети та місії діяльності підприємства; 2) оцінка впливу, факторів макро- та мікросередовища на діяльність підприємства, сучасної економічної, технічної й технологічної позиції підприємства, з аналізом стратегічних альтернатив; 3) формування маркетингової стратегії з визначенням тактичних завдань та пріоритетів у процесі її реалізації.

Оцінивши сорормульовану маркетингову стратегію і потребу в інвестиціях, приймають остаточне рішення щодо її реалізації. Якщо воно негативне, повертаються до аналізу й починають повторну роботу. Якщож сорормульована стратегія всіх управлінців влаштовує, її затверджують; на її основі та корпоративній стратегії фрормують свої стратегії фрункціональні підрозділи, а маркетингова стратегія доводиться до виконавців і починається робота по її реалізації, контролю і коректуванню.

\section{ВИСНОВКИ}

У сучасних умовах кожне підприємство повинно ефективно управляти своєю стратегічною діяльністю. Зокрема потрібно аналізувати ринкові можливості, відбирати цільові ринки, розробляти ефективний комплекс маркетингу й успішно управляти впровадженням у життя маркетингових заходів. Таким чином, маркетингові інструменти стратегічного управління - це комплекс базових рішень, спрямованих на досягнення мети підприємства з урахуванням власних можливостей, а також факторів навколишнього середовища. Саме ефективна маркетингова стратегія допоможе підприємству функціонувати у несприятливому зовнішньому середовищі.

\section{Література:}

1. Ансофрф И. Стратегическое управление: учеб. для вузов / И. Ансоффф. - М.: Экономика, 1989. - 454 с.

2. Березін О.В. Стратегія підприємства: навч. посіб. / О.В. Березін, М.Г. Безпарточний. - К.: Ліра-К, 2010. $-224 \mathrm{c}$.

3. Друкер П. Менеджмент: учебник / П. Друкер, Дж.А. Макьярелло. - М.: ООО "И.Д. Вильямс", 2010. $-704 \mathrm{c}$.

4. Лабурцева О.І. Стратегічний маркетинг: конс. лек. для студент. / О.І. Лабурцева. - К.: КНУТД, 2012. $31 \mathrm{c}$.

5. Минцберг Г. Школы стратегий : учеб. для вузов / Г. Минцберг, Б. Альстрэд, Дж. Лэмпел. - СПб.: Питер, 2000. -336 c.

6. Міщенко А.П. Стратегічне управління: навч. посіб. / А.П. Міщенко. - К.: "Центр навчальної літератури", 2004. - $336 \mathrm{c}$.

7. Обремчук В.Ф. Стратегія підприємства: курс лекцій / В.Ф. Обремчук. - К.: МАУП, 2000. - 128 с.

8. Портер М. Стратегія конкуренції і методика аналізу галузей і діяльності конкурентів: навч. посіб. / М. Портер. - К.: Основи, 2007. - 451 с.

9. Томпсон А.А. Стратегический менеджмент: концепции и ситуации для анализа / А.А. Томпсон, А.Дж. Стрикленд. - М.: Издательский дом "Вильямс", 2007. - 928 с.

10. Турченюк М.О. Маркетинг: підручник / М.О. Турченюк, М.Д. Швець. - К.: Знання, 2011. - 320 с.

11. Шершньова 3.Є. Стратегічне управління: підручник / З.Є. Шершньова. - К.: КНЕУ, 2004. - 699 с.

\section{References:}

1. Ansoff, I. (1989), Strategicheskoye upravleniye [Strategic management], Economics, Moscow, Russia.

2. Berezin, O. V. and Bezpartochnyj, M. H. (2010), Stratehiya pidpryyemstva [Enterprise strategy], Lira-K, Kyiv, Ukraine.

3. Drucker, P. and Mak'iarello, Dzh. A. (2010), Menedzhment [Management], LLC "I. D. Williams", Moscow, Russia.

4. Laburtseva, O. I. (2012), Stratehichnyy marketynh [Strategic Marketing], KNUTD, Kyiv, Ukraine.

5. Mintzberh, H. Al'stred, B. andLempel, Dzh. (2000), Shkoly strategiy [School of strategies], SPb, Peter, Russia.

6. Mishenko, A. P. (2004), Stratehichne upravlinnya [Strategic Management], CEL, Kyiv, Ukraine.

7. Obremchuk, V. F. (2000), Stratehiya pidpryyemstva [Enterprise strategy], IAPM, Kyiv, Ukraine.

8. Porter, M. (2007), Stratehiya konkurentsiyi i metodyka analizu haluzey i diyal'nosti konkurentiv [Competition strategy and methods of analysis of industries and activities of competitors], Fundamentals, Kyiv, Ukraine.

9. Thompson, A. A. and Stryklend, A. Dzh. (2007), Strategicheskiy menedzhment: kontseptsii i situatsii dlya analiza [Strategic management: concepts and situations for analysis], Williams Publishing House, Moscow, Russia.

10. Turchenyuk, M. O. and Shvets', M. D. (2011), Marketynh [Marketing], Knowledge, Kyiv, Ukraine.

11. Shershnova, Z. (2004), Strategicheskoe ypravlinnya [Strategic management], KNEU, Kyiv, Ukraine. Cтаття надійшла до редакцї 18.10.2019p. 